\title{
EFFECTS OF HIGH TEMPERATURE ON PHOTOSYNTHESIS AND YIELD IN MUNGBEAN
}

\author{
MD TARIQUL ISLAM* \\ Crop Physiology Division, Bangladesh Institute of Nuclear Agriculture (BINA), \\ Mymensingh-2202, Bangladesh
}

Key words: Photosynthesis, Temperature, Growth stage, Mungbean yield

\begin{abstract}
Temperature $\left(36^{\circ} \mathrm{C}\right)$ at pre-flowering stage of mungbean showed lower leaf conductance than others. Photosynthesis decreased but transpiration rate was not affected by the temperature treatments. Ambient temperature showed the highest yield. Yields at the temperature $36^{\circ} \mathrm{C}$ at pre-flowering, flowering and grain filling stages were identical.

Mungbean (Vigna radiata L. Wilczek) is one of the most important crops of global economic importance. It has raceme type of inflorescence with asynchronous flowering and poding. It has yield potential of around $2000 \mathrm{~kg} / \mathrm{ha}$ but productivity is low $(864 \mathrm{~kg} / \mathrm{ha})$. The number of fruits with developing seeds increases after fruit setting stage and reaches to maximum seed growth stage but during this period the plant is still growing vegetative. Therefore, developing reproductive sinks are competing for assimilates with vegetative sinks. Number of fruits and seeds is related with photosynthetic rate that determines through leaf area and dry matter production. Per cent solar radiation interception and rate of dry matter production increased with leaf area development (Hamid et al. 1990). Mungbean yield is predetermined by the potential of a given variety and the environment. Optimum temperature for potential yield of mungbean lies between $28-30^{\circ} \mathrm{C}$ (Poehlman 1991). High temperature affects yield in mungbean (Khattak et al. 2009, Singh and Singh 2011). Increases in temperature resulted in changes in the fluorescence parameters nonphotochemical quenching (qN) and photochemical quenching (qP) in two varieties of beans, but to a different extent (Pastenes and Horton 1996). In Bangladesh, mungbean is cultivated in winter and summer and both low and high temperature affects its growth and yield. Summer varieties are often facing high temperature $\left(34-38^{\circ} \mathrm{C}\right)$ during April - May. But information regarding their tolerance to high temperature is miger. When physiological basis of yield and yield-forming components under such temperature stress are understood, it is possible to improve yields of a mungbean crop. So, effect of temperature at different growth stages of eight mungbean varieties was investigated with respect to photosynthesis and yield.

Two pot experiments were conducted to evaluate summer mungbean genotypes during March to May 2010 and 2011 at BINA, Mymensingh, Bangladesh. Eight mungbean varieties viz., Binamoog-2, Binamoog-5, BARImung-5, Binamoog-6, Binamoog-7, Binamoog-8, BU moog- and BU moog- were used in this study. Each pot contained $8 \mathrm{Kg}$ of soils (Silty loam, organic matter $1.05 \%$, total N $0.07 \%$, available P 14.3 ppm, exchangeable K 0.25 meq.per $100 \mathrm{~g}$ soil, available S 13.2 and soil $\mathrm{pH}$ 6.67). The experiment was laid out in a CRD with three replications. Recommended doses of fertilizers were applied and other cultural practices were followed as and when required. Temperature treatments viz., (i) Ambient $\left(27^{\circ} \mathrm{C}\right.$, (ii) $36^{\circ} \mathrm{C}$ at pre-flowering, (iii) $36^{\circ} \mathrm{C}$ at flowering and (iv) $36^{\circ} \mathrm{C}$ at pod filling stages of mungbean varieties. Temperature $36^{\circ} \mathrm{C}$ was imposed for 7 days in controlled plant growth chamber ( $\left.\mathrm{RH} 80 \%, \mathrm{CO}_{2} 330 \mathrm{ppm}\right)$. Ambient temperature was recorded $27-32^{\circ} \mathrm{C}$ during pre-flowering, flowering and maturity stages of
\end{abstract}

*Author for correspondence: <islamtariqu105@yahoo.com> 
mungbean varieties. Photosynthesis, leaf conductance and transpiration were recorded using Portable Photosynthesis System LI-6400XT, LI-COR Inc., Lincoln, NE, USA. Partitioning of dry matter and yield attributes were taken at maturity. Statistical analysis was done as per design used with the help of MSTAT computer packages. DMRT compared the means at 5\% level of significance.

Table 1. Effect of temperature on photosynthesis, leaf conductance and transpiration rate of mungbean varieties.

\begin{tabular}{llll}
\hline Treatment & Pn & Cond & Tr \\
\hline Temperature imposed & & & \\
Ambient & $26.21 \mathrm{a}$ & $0.25 \mathrm{a}$ & 3.72 \\
$36^{\circ} \mathrm{C}$ at pre-flowering stage & $23.99 \mathrm{~b}$ & $0.24 \mathrm{~b}$ & 3.71 \\
$36^{\circ} \mathrm{C}$ at flowering stage & $23.85 \mathrm{~b}$ & $0.25 \mathrm{a}$ & 3.70 \\
$36^{\circ} \mathrm{C}$ at pod filling stage & $23.96 \mathrm{~b}$ & $0.25 \mathrm{a}$ & 3.71 \\
Genotypes & & & \\
Binamoog-5 & $23.31 \mathrm{de}$ & $0.22 \mathrm{e}$ & $3.21 \mathrm{f}$ \\
Binamoog-6 & $23.53 \mathrm{~d}$ & $0.24 \mathrm{~d}$ & $3.40 \mathrm{e}$ \\
BU Mung-1 & $27.35 \mathrm{a}$ & $0.28 \mathrm{a}$ & $4.44 \mathrm{a}$ \\
BU mung-2 & $26.14 \mathrm{~b}$ & $0.26 \mathrm{~b}$ & $4.13 \mathrm{~b}$ \\
BU Mung-4 & $25.59 \mathrm{c}$ & $0.25 \mathrm{c}$ & $3.91 \mathrm{c}$ \\
BARI mung-2 & $23.59 \mathrm{~d}$ & $0.24 \mathrm{~d}$ & $3.75 \mathrm{~d}$ \\
Binamoog-2 & $23.55 \mathrm{~d}$ & $0.24 \mathrm{~d}$ & $3.43 \mathrm{e}$ \\
Binamoog-7 & $23.08 \mathrm{e}$ & $0.23 \mathrm{e}$ & $3.39 \mathrm{e}$ \\
Year & & & \\
2010 & $24.39 \mathrm{~b}$ & $0.24 \mathrm{~b}$ & $3.69 \mathrm{~b}$ \\
2011 & $24.64 \mathrm{a}$ & $0.25 \mathrm{a}$ & $3.73 \mathrm{a}$ \\
CV\% & 3.04 & 4.63 & 3.48 \\
\hline
\end{tabular}

Values having common letter(s) in a column do not differ significantly at 5\% level as per DMRT. Where, $\mathrm{Pn}=$ Photosynthetic rate $\left(\mu \mathrm{mol} \mathrm{CO} \mathrm{Cm}^{-2} \mathrm{~s}^{-1}\right)$, Cond = Leaf conductance $\left(\mathrm{mol} \mathrm{H} \mathrm{O} \mathrm{m}^{-2} \mathrm{~s}^{-1}\right), \mathrm{Tr}=\mathrm{Transpiration}$ rate $\left(\mathrm{mol} \mathrm{H}_{2} \mathrm{Om}^{-2} \mathrm{~s}^{-1}\right)$

Temperature $\left(36^{\circ} \mathrm{C}\right)$ at pre-flowering, flowering and pod filling stages decreased photosynthetic rates which were identical (Table 1). Temperature $36^{\circ} \mathrm{C}$ at pre-flowering stage had lower leaf conductance than others. Transpiration rate was not affected by the temperature treatments. Temperature $36^{\circ} \mathrm{C}$ at pre-flowering, flowering and pod filling stages decreased pod weights compared to ambient. Ambient temperature showed the highest yield. Yields at the temperature $36^{\circ} \mathrm{C}$ at pre-flowering, flowering and grain filling stages were identical. Binamoog-5 produced the highest pod weight, yield/plant and lower photosynthetic rate, leaf conductance and transpiration rate. Binamoog-6 showed identical yield/plant to Binamoog-5. BU Mung-1 had the highest photosynthetic rate, leaf conductance, transpiration rate and lower pod weight and seed yield/plant. BU mung-2 produced lower pod weight and yield/plant. BU Mung-4 and BARI mung2 showed medium photosynthetic rate, leaf conductance, transpiration rate, pod weight and seed yield/plant. Binamoog-2 and Binamoog-7 had lower photosynthetic rate, transpiration rate, medium pod weight and seed yield/plant.

Temperature $36^{\circ} \mathrm{C}$ at pre-flowering, flowering and pod filling stages decreased seed yield. High temperature may shed flowers due to some hormonal changes or failure in fertilization. The 
failure in hybridization could be due to the indehiscence of anthers or because drying up of stigma and overy of the flowers due to high temperature. High temperature during flowering causes huge flowers' sheding. Genetic differences for number of flowers produced in mungbean have been reported (Khattak 2006) but genetic tolerance for flowers' sheding under high temperature is absent in the existing germplasm of this crop (Khattak 2006). Temperature $36^{\circ} \mathrm{C}$ at pre-flowering stage affected photosynthesis and pod development. The results are in agreement with those of Karim et al. (2003),Vijaylami and Bhattacharya (2007). Photosynthesis has generally considered being the primary factor affecting the dry matter production in crop plants. The dry matter production and its subsequent conversion into economic yield are the result of a complex physiological process within plants. One of the most stress responses in plant overproduction of different types of compatible organic solutes viz. proline, GB, ABA, soluble sugars and inorganic

Table 2. Effect of temperature at different growth stages on yield of mungbean varieties.

\begin{tabular}{lcl}
\hline Treatment & Pod wt. (g)/plant & Yield (g) /plant \\
\hline Temperature imposed & & \\
Ambient & $13.45 \mathrm{a}$ & $11.17 \mathrm{a}$ \\
$36^{\circ} \mathrm{C}$ at pre-flowering stage & $10.58 \mathrm{~b}$ & $8.31 \mathrm{~b}$ \\
$36^{\circ} \mathrm{C}$ at flowering stage & $10.59 \mathrm{~b}$ & $8.34 \mathrm{~b}$ \\
$36^{\circ} \mathrm{C}$ at pod filling stage & $10.87 \mathrm{~b}$ & $8.47 \mathrm{~b}$ \\
Genotypes & & \\
Binamoog-5 & $12.60 \mathrm{a}$ & $10.01 \mathrm{a}$ \\
Binamoog-6 & $11.71 \mathrm{~b}$ & $9.49 \mathrm{ab}$ \\
BU Mung-1 & $10.75 \mathrm{c}$ & $8.60 \mathrm{~d}$ \\
BU mung-2 & $10.84 \mathrm{c}$ & $8.64 \mathrm{~d}$ \\
BU Mung-4 & $10.77 \mathrm{c}$ & $8.68 \mathrm{~d}$ \\
BARI mung-2 & $10.88 \mathrm{c}$ & $8.77 \mathrm{~cd}$ \\
Binamoog-2 & $11.60 \mathrm{~b}$ & $9.09 \mathrm{bcd}$ \\
Binamoog-7 & $11.83 \mathrm{~b}$ & $9.30 \mathrm{bc}$ \\
Year & & \\
2010 & $11.56 \mathrm{a}$ & $9.23 \mathrm{a}$ \\
2011 & $11.18 \mathrm{~b}$ & $8.92 \mathrm{~b}$ \\
CV\% & 10.66 & 10.15 \\
\hline
\end{tabular}

Values having common letter(s) in a column do not differ significantly at 5\% level as per DMRT.

ions like $\mathrm{K}^{+}$. These are of low molecular weights highly soluble compounds that are non toxic at high cellular concentrations and protect plants again stress, including contribution to cellular osmoic adjustment, detoxification of reactive oxygen species, protection of membrane integrity and stabilization of engymes proteins (Bohnert and Jensen 1996). The physiological role of heat shock proteins may play the organisms from injury under high temperature. These heat shock proteins can associate with plasmalemma and cellular organelles, such as ribosomes, mitrochondria, chloroplasts and nuclei etc. under high temperature. 


\section{References}

Bohnert HJ and RG Jensen 1996. Strategies for engineering water-stress tolerance in plants. Trends Biotechnol. 14: 89-97.

Hamid MA, W Agata, Y Kawamitsu 1990. Photosynthesis, transpiration and water use efficiency in four cultivars of mungbean. Photosynthetica 24: 96-101.

Karim A, H Fukamachi and T Hidaka 2003. Photosynthetic performance of Vigna radiata L. leaves developed at different temperature and irradiance levels. Plant Sci. 164: 454-458.

Khattak GSS, I Saeed and T Muhammad 2006. Breeding for heat tolerance in mungbean (Vigna radiata $\mathrm{L}$. Wilczek). Pak J. Bot. 38: 1539-1550.

Khattak GSS, I Saeed and T Muhammad 2006. Breeding for abiotic stresses in mungbean (Vigna radiata L. Wilczek). Pak J. Bot. 41: 35-39.

Pastenes C and P Horton 1996. Effect of high temperature on photosynthesis in beans (I. Oxygen evolution and chlorophyll fluorescence). Plant Physiol. 112: 1245-1251.

Poehlman JM 1991. The Mungbean, Oxford and IBH Publishing Co. Pvt. Ltd. pp. 27-30. New Delhi.

Singh DP and BB Sing 2011. Breeding for tolerance to abiotic stresses in mungbean. J. Food Legumes. 24: 83-90.

Vijaylami and Bhattacharya 2007. Mungbean seed yield: i. Effect of dry matter yield under drought conditions? Plant Cell Environ. 25: 333-341.

(Manuscript received on 27 November, 2014; revised on 4 May, 2015) 